\title{
NKG2D-Mediated Cytotoxicity toward Oligodendrocytes Suggests a Mechanism for Tissue Injury in Multiple Sclerosis
}

\author{
Philippe Saikali, ${ }^{1}$ Jack P. Antel, ${ }^{1}$ Jia Newcombe, ${ }^{3}$ Zhihong Chen, ${ }^{4}$ Mark Freedman, ${ }^{4}$ Manon Blain, ${ }^{1}$ Romain Cayrol, ${ }^{5}$ \\ Alexandre Prat, ${ }^{5}$ Jeffery A. Hall, ${ }^{2}$ and Nathalie Arbour ${ }^{1,5}$ \\ ${ }^{1}$ Neuroimmunology Unit, Montreal Neurological Institute, and 2Division of Neurosurgery, McGill University, Montreal, Quebec, Canada H3A 2B4, \\ ${ }^{3}$ NeuroResource, University College London, Institute of Neurology, London WC1N 1PJ, United Kingdom, ${ }^{4}$ Ottawa Hospital, University of Ottawa, Ottawa, \\ Ontario, Canada K1H 8L6, and 5 Research Center-Centre Hospitalier de l'Université de Montréal, University of Montreal, Montreal, Quebec, Canada H2L 4M1
}

\begin{abstract}
NKG2D is an activating or coactivating receptor expressed on human natural killer (NK) cells, CD8 ${ }^{+} \mathrm{T}$ cells, and $\gamma / \delta \mathrm{T}$ cells. NKG2D ligands have been detected on many tumor cell types and can be induced on nontransformed cells by environmental signals including DNA damage and inflammation. We investigated the contribution of NKG2D-NKG2D ligand interaction on CNS-directed immune responses. We observed that primary cultures of human adult oligodendrocytes and fetal astrocytes expressed ligands for NKG2D in vitro whereas neurons, microglia, and adult astrocytes did not. Disruption of the NKG2D-NKG2D ligand interaction using blocking antibodies significantly inhibited killing of primary human oligodendrocytes mediated by activated human NK cells, $\gamma / \delta$ T cells, and allo-reactive $\mathrm{CD}^{+}$T cells. NKG2D ligands [major histocompatibility complex class I chain-related molecules A and B (MICA/B)] were detected in groups of cells and colocalized with an oligodendrocyte marker (adenomatous polyposis coli) in white matter sections obtained from multiple sclerosis lesions but not in normal control samples. CD8 ${ }^{+}$T cells could be detected in close proximity to MICA/B + cells within multiple sclerosis lesions, supporting an in vivo interaction between these immune effectors and stressed MICA/B-expressing oligodendrocytes. These results imply that NKG2D-NKG2D ligand interaction can potentially contribute to cytotoxic responses mediated by activated immune effector cells in the inflamed CNS, as observed in multiple sclerosis.
\end{abstract}

Key words: oligodendrocytes; multiple sclerosis; human; astrocytes; autoimmunity; lymphocytes

\section{Introduction}

Multiple sclerosis (MS), an inflammatory disease of the CNS is characterized by injury to oligodendrocytes, which are responsible for the synthesis and maintenance of myelin, and axonal loss. The contribution of multiple immune mediators detected within MS lesions to the observed tissue injury remains to be defined (Sospedra and Martin, 2005). Although myelin-specific T cells have been recovered from MS lesions and shown to contribute to the pathogenesis of animal models, limited data exist regarding their contribution to oligodendrocytic/neuronal cell-directed cytotoxicity. Transgenic mice overexpressing proteolipid protein showed myelin debris engulfed by macrophages, enhanced MHC class I expression on oligodendrocytes, and activated memory $\mathrm{CD}^{+}{ }^{+} \mathrm{T}$ cells in close contact with the myelinating cells (Ip et al., 2006). Human oligodendrocytes are susceptible to MHC class I restricted $\mathrm{CD} 8{ }^{+} \mathrm{T}$ cell-mediated cytotoxicity in vitro (Jurewicz et

Received Aug. 16, 2006; revised Dec. 15, 2006; accepted Dec. 24, 2006.

This study was supported by a grant from the Canadian Institutes of Health. N.A. is supported by a Senior Research Fellowship from the Canadian Institutes of Health Research (CIHR). P.S. is supported by a studentship from the CIHR neuroinflammation training program (2005) and a studentship from the Multiple Sclerosis Society of Canada (2006). We are grateful for the technical assistance of Ellie McCrea and Carolyn Jack. We acknowledge the contribution of Dr. André Oliver, who provided adult human CNS tissues.

Correspondence should be addressed to Nathalie Arbour, Research Center-Centre Hospitalier de I'Université de Montréal, University of Montreal, Pavilion JA DeSeve (Y-3609), 1560 Sherbrooke East, Montreal, Quebec, Canada H2L 4M1. E-mail: nathalie.arbour@umontreal.ca.

DOI:10.1523/JNEUROSCI.4402-06.2007

Copyright $\odot 2007$ Society for Neuroscience $\quad$ 0270-6474/07/271220-09\$15.00/0 al., 1998; Bien et al., 2002) and to non-MHC restricted cytotoxicity mediated by $\gamma \delta$ T cells (Freedman et al., 1991) and cytokineactivated natural killer (NK) cells (Morse et al., 2001). No information is available on potential common mechanisms used by these immune effectors to specifically kill oligodendrocytes and not other glial cells.

NKG2D is an activating or coactivating receptor on human $\mathrm{NK}, \gamma / \delta \mathrm{T}$, and $\alpha / \beta \mathrm{CD} 8^{+} \mathrm{T}$ cells. NKG2D engagement on NK or $\gamma / \delta \mathrm{T}$ cells stimulates the secretion of cytokines and release of cytolytic granules (Raulet, 2003; Andre et al., 2004; RinconOrozco et al., 2005). NKG2D is a costimulatory molecule for the T-cell receptor (TCR)-mediated activation of $\mathrm{CD}^{+} \mathrm{T}$ cells (Groh et al., 2001; Maasho et al., 2005); high levels of interleukin-15 (IL-15) can also arm activated effector CD8 ${ }^{+} \mathrm{T}$ cells to kill target cells in an NKG2D-restricted manner, regardless of the TCR specificity (Meresse et al., 2004).

NKG2D interacts with a family of ligands that respond to environmental triggers (i.e., stress, transformation, infection, or inflammation), suggesting that these proteins could play a role in alerting the immune system to the abnormal state of the ligandexpressing cells. The ligands include the MHC class I chainrelated molecules (MICs): MICA and MICB, and the UL16binding protein (ULBP) family (ULBP1, ULBP2, ULBP3, and ULBP4) (Raulet, 2003; Lanier, 2005). MICs have been detected in healthy humans only on intestinal and thymic epithelial cells, endothelial cells, and fibroblasts (Groh et al., 1996; Bahram, 
2000). In contrast, mRNAs encoding for ULBPs have been detected in multiple normal tissues (Cosman et al., 2001), although ULBP protein expression has not been shown in these organs (Raulet, 2003). Pathogens or DNA damage can induce the expression of MICs or ULBPs on different cell types (Groh et al., 2001; Tieng et al., 2002; Welte et al., 2003; Gasser et al., 2005). Upregulated NKG2D ligands have been reported in target organs of inflammatory diseases such as celiac disease (Hue et al., 2004) and rheumatoid arthritis (Groh et al., 2003), but such expression has not been reported for CNS inflammatory diseases.

The current study investigates whether immune mediator engagement of NKG2D ligands expressed on CNS target cells could contribute to the selective tissue injury that characterizes MS.

\section{Materials and Methods}

Isolation of adult human oligodendrocytes and astrocytes. Tissue was obtained from surgical resections performed for the treatment of nontumor-related intractable epilepsy, in accordance with the guidelines set by the Biomedical Ethics Unit of McGill University. Oligodendrocytes were isolated from adult human brain as described previously (D'Souza et al., 1995; Jurewicz et al., 1998). Briefly, brain tissue was digested with trypsin and DNase I, mechanically dissociated, and then separated on a $30 \%$ Percoll gradient (GE Healthcare, Uppsala, Sweden). Washed mixed glial cells were plated in MEM (Sigma, St. Louis, MO) supplemented with $5 \%$ FCS (Sigma), glucose, glutamine, and antibiotics (complete MEM) for $24 \mathrm{~h}$. The less-adherent oligodendrocytes were harvested and transferred to another tissue culture flask for an additional $24 \mathrm{~h}$ to further enrich for oligodendrocytes. The nonadherent oligodendrocytes were collected and plated onto poly-L-lysine-coated 16-well chamber slides (Nalge Nunc International, Naperville, IL) at a density of $1 \times 10^{5}$ cells/ well in complete MEM. Oligodendrocytes were used 1 week later. We detached the mixed population of adherent cells obtained from the cells plated on the second day and analyzed them by flow cytometry as described below and could identify adult astrocytes with a cell-specific labeling [see below, anti-glial fibrillary acidic protein (GFAP)]. In some experiments, adult oligodendrocytes were treated for $2 \mathrm{~d}$ with TNF- $\alpha$ $(2000 \mathrm{U} / \mathrm{ml}=20 \mathrm{ng} / \mathrm{ml}$; Biosource, Camarillo, CA $)$ plus IFN- $\gamma(200$ $\mathrm{U} / \mathrm{ml}=3.6 \mathrm{ng} / \mathrm{ml}$; Biosource $)$ or IFN- $\alpha+\mathrm{IFN}-\beta(1000 \mathrm{U} / \mathrm{ml}$ each, both from Biosource).

Isolation of human fetal astrocytes, microglia, and neurons. Human fetal CNS tissue obtained from 14- to 23-week-old embryos was provided by the Human Fetal Tissue Repository, Albert Einstein College of Medicine (Bronx, NY). The studies were approved by their and our institutional review boards. Astrocytes, neurons, and microglia were isolated from human fetal CNS tissues as described previously (D'Souza et al., 1995). Diced brain tissue was dissociated with trypsin and DNase I followed by mechanical dissociation. To derive neurons, $2 \times 10^{6}$ cells/well were seeded on poly-L-lysine ( $10 \mu \mathrm{g} / \mathrm{ml}$, Sigma) coated 24-well plates in MEM supplemented with 5\% FCS, antibiotics, glutamine, and glucose. Cells were subjected to three cycles of $1 \mathrm{~mm} 5^{\prime}$-deoxy-5-fluorouridine (Dfu) every $4 \mathrm{~d}$ to kill dividing astrocytes. Neurons were used $2 \mathrm{~d}$ after the last addition of Dfu. To obtain astrocytes, the initial mixed CNS cell culture grown in DMEM supplemented with 10\% FCS, antibiotics, glutamine, and glucose, and was passaged three times when confluent, starting at 2 weeks after isolation using trypsin-EDTA. Microglia were harvested from the supernatant of these mixed cultures. In some experiments, CNS cells were treated for 1 or $3 \mathrm{~d}$ with IL- $1 \beta$ ( $10 \mathrm{ng} / \mathrm{ml}$; Medicorp, Montreal, QC) or TNF- $\alpha(2000 \mathrm{U} / \mathrm{ml}=20 \mathrm{ng} / \mathrm{ml})$ plus IFN- $\gamma(200 \mathrm{U} / \mathrm{ml}=3.6 \mathrm{ng} / \mathrm{ml})$.

Isolation and activation of human NK cells. Healthy donors' peripheral blood mononuclear cells (PBMCs) were isolated from venous blood samples using a Ficoll density gradient (GE Healthcare). Cells were cultured for $3 \mathrm{~d}$ at 2 to $4 \times 10^{6}$ cells/ml with $100 \mathrm{U} / \mathrm{ml}$ of IL-2 (Roche, Mississauga, Ontario, Canada) in Roswell Park Memorial Institute (RPMI) supplemented with 10\% FCS, antibiotics, and glutamine. After the in vitro culture, $\mathrm{T}$ cells were depleted using the CD3 Microbeads (Miltenyi Biotec, Auburn, CA) following the manufacturer's instructions, followed by a CD56-positive selection to enrich for NK cells. Cells obtained were over $93 \%\left(\mathrm{CD} 3^{-} \mathrm{CD}^{+} 6^{+}\right)$pure, as verified by flow cytometry.

Expansion and isolation of human $\gamma \delta T$ cells. Human $\gamma \delta$ T cells were expanded and isolated as described previously (Zeine et al., 1998). Briefly, 24-well plates were precoated with sheep anti-mouse IgG1 antibody (The Binding Site, Birmingham, UK), washed with PBS, blocked with FCS, and then coated with anti-TCR $\gamma \delta$. PBMCs isolated from MS patients were cultured on these precoated plates at a density of $1 \times 10^{6}$ cells/ml in RPMI supplemented with 10\% FCS, 2 mm glutamine, and antibiotics. IL-2 (50 U/ml) (courtesy of Chiron, Emeryville, CA) was added on the following day. On day 5 , cells were collected and resuspended at $4 \times 10^{5}$ cells $/ \mathrm{ml}$ in serum-free media AIM-V (Invitrogen, Eugene, OR), and cultured for another 4 or $5 \mathrm{~d}$ with fresh IL-2. Purity of cells was verified by flow cytometry; when $\gamma \delta$ T cells represented $<90 \%$, $\alpha \beta$ T cells were then eliminated with complement lysis using anti-CD4 and anti-CD8 (Caltag, Burlingame, CA) monoclonal antibodies, as described previously (Zeine et al., 1998). Purified cells were used within a week after complement lysis.

Expansion of human allo-reactive $C D 8^{+} T$ cells. Healthy donors' PBMCs were isolated from venous blood samples using a Ficoll density gradient (GE Healthcare). Cells were cultured for 1 week at $2 \times 10^{6}$ cells $/ \mathrm{ml}$ in Isove's medium supplemented with $7.5 \%$ human $\mathrm{AB}$ serum, antibiotics and glutamine in the presence of irradiated allogeneic expanded B cells $\left(5 \times 10^{5}\right.$ cells $\left./ \mathrm{ml}\right)$. CD8 ${ }^{+} \mathrm{T}$ cells were then purified using the CD8 Microbeads (Miltenyi Biotec, Auburn, CA) following manufacturer's instructions and then put in culture with fresh irradiated allogeneic B cells. Allo-reactive $\mathrm{CD} 8^{+} \mathrm{T}$ cells were restimulated once a week with the same allogeneic B cells at a 5:1 ratio $(5 \mathrm{~T}: 1 \mathrm{~B})$ with the addition of IL-2 $(50 \mathrm{U} / \mathrm{ml})$ between antigenic stimulation. Allo-reactive CD8 ${ }^{+} \mathrm{T}$ cells were used $4 \mathrm{~d}$ after the third or the fourth antigenic round in killing assays. Cells obtained were over $95 \%\left(\mathrm{CD} 3{ }^{+} \mathrm{CD} 8{ }^{+}\right)$pure, as verified by flow cytometry.

Flow cytometry analysis. Fetal and adult astrocytes, fetal neurons, and adult oligodendrocytes were detached using PBS containing 1 mм EDTA before being stained. Surface staining was performed using fluorescenceactivated cell sorting (FACS) buffer (PBS containing 1\% FCS and $0.1 \%$ sodium azide). To stain for NKG2D ligands, cells were incubated with Abs against MICA (clone M673), MICB (clone M360), ULBP1 (clone M292), ULBP2 (clone M311), and ULBP3 (clone M511) (kindly provided by Amgen, Seattle, WA) as used previously by other groups (Salih et al., 2003; Carbone et al., 2005), or the isotype control (IgG1), washed twice, then incubated with phycoerythrin (PE)- or allophycocyanin (ALPC)-labeled goat anti-mouse Abs (BD Biosciences, Mississauga, Ontario, Canada), and then fixed in $1 \%$ formaldehyde containing PBS. When CNS cells were available in limited numbers, we tested the MICA and MICB Abs together in the same sample and the ULBP1, ULBP2, and ULBP3 Abs together as well. Oligodendrocytes were stained for galactocerebroside (GalC) (using hybridoma $\mathrm{H} 8 \mathrm{H} 9$, a kind gift from V. Wee Yong, University of Calgary, Calgary, Alberta, Canada) followed by secondary Abs as described above. Intracellular staining was performed by fixing and permeabilizing the cells for $10 \mathrm{~min}$ at room temperature with paraformaldehyde/saponin buffer [4\% (w/v) paraformaldehyde, $0.1 \%$ $(\mathrm{w} / \mathrm{v})$ saponin, and $10 \mathrm{~mm}$ HEPES in HBSS]. After two washes with saponin buffer $[0.1 \%(\mathrm{w} / \mathrm{v})$ saponin in FACS buffer], cells were incubated with Alexa-488 conjugated anti-GFAP antibodies (Invitrogen) for astrocytes, anti-tubulin III (Sigma) followed by secondary Abs (PE- or ALPC-labeled goat anti-mouse Abs) for neurons, or fluorescein isothiocyanate (FITC)-conjugated anti-CD68 for microglia. Isotypes matched for concentration of primary Abs were used for all stainings. Immune cells were stained with fluorochrome-conjugated Abs against CD3, CD4, CD8, CD56, $\gamma \delta$ TCR, and NKG2D (all from BD Biosciences). Cells were then washed twice with FACS buffer and fixed in $1 \%$ formaldehyde. All results were acquired on an FACSCalibur (BD Biosciences) and analyzed with FlowJo software (Treestar, Ashland, OR).

$R N A$ isolation, reverse transcription, and $q-P C R$. Total RNA was isolated using TRIzol (Invitrogen) and the Qiagen (Mississauga, Ontario, Canada) RNeasy mini kit according to the manufacturer's instructions and as described previously (Jack et al., 2005). RNA samples were treated with DNase (Qiagen) and then transcribed into cDNA using random 
Table 1. Antibodies used for immunohistochemistry on human brain sections

\begin{tabular}{|c|c|c|c|c|}
\hline Antigen/antibody & Isotype & Commercial source & Concentration used & Secondary and tertiary used \\
\hline $\mathrm{MICA} / \mathrm{B}$ & Mouse $\lg G 2 a$ & BD Biosciences & $25 \mu \mathrm{g} / \mathrm{ml}$ & $\begin{array}{l}\text { Goat anti-mouse biotin } \\
\text { Streptavidin-Cy3 }\end{array}$ \\
\hline $\mathrm{APC}-\mathrm{CC} 1$ & Mouse $\lg \mathrm{G} 1$ & Calbiochem (La Jolla, CA) & $2 \mu \mathrm{g} / \mathrm{ml}$ & Goat anti-mouse FITC \\
\hline MAG & Mouse lgG1 & Millipore (Temecula, CA) & $5 \mu \mathrm{g} / \mathrm{ml}$ & $\begin{array}{l}\text { Goat anti-mouse biotin } \\
\text { Streptavidin-Cy3 }\end{array}$ \\
\hline GFAP-Alexa 488 & Mouse lgG1 & Invitrogen & $10 \mu \mathrm{g} / \mathrm{ml}$ & NONE \\
\hline CD8-allophycocyanin & Mouse lgG1 & BD Biosciences & $3 \mu \mathrm{g} / \mathrm{ml}$ & $\begin{array}{l}\text { Rabbit anti-APC } \\
\text { Donkey anti-rabbit FITC }\end{array}$ \\
\hline Goat anti-mouse biotin & n.a. & Dako (Carpinteria, CA) & $9 \mu \mathrm{g} / \mathrm{ml}$ & n.a. \\
\hline Streptavidin-Cy3 & n.a. & Jackson ImmunoResearch (West Grove, PA) & $3.6 \mu \mathrm{g} / \mathrm{ml}$ & n.a. \\
\hline Rabbit anti-APC & n.a. & Biomeda (Cedarlane, Burlington, Ontario, Canada) & $10 \mu \mathrm{g} / \mathrm{ml}$ & n.a. \\
\hline Donkey anti-rabbit FITC & n.a. & Jackson ImmunoResearch & $15 \mu \mathrm{g} / \mathrm{ml}$ & n.a. \\
\hline Goat anti-mouse FITC & n.a. & Biosource & $14.8 \mu \mathrm{g} / \mathrm{ml}$ & n.a. \\
\hline
\end{tabular}

n.a., Not applicable.

hexaprimers (Roche) with the Moloney murine leukemia virus-reverse transcription enzyme (Invitrogen) at $42^{\circ} \mathrm{C}$. Expression levels for MICA and MICB were determined by quantitative real-time PCR (q-PCR) using the ABI PRISM 7700 Sequence Detection System (Applied Biosystems, Foster City, CA). Primers and TaqMan fluorescein-labeled minor groove binder probes for MICA and MICB were obtained from Applied Biosystems (TaqMan gene expression assays). $\beta$-Actin primers and cycling used have been published previously (Jack et al., 2005). q-PCR cycling was performed according to the ABI PRISM 7000 Sequence Detection System default temperature settings $\left(2 \mathrm{~min}\right.$ at $50^{\circ} \mathrm{C}, 10 \mathrm{~min}$ at $95^{\circ} \mathrm{C}$, followed by 40 cycles of $15 \mathrm{~s}$ at $95^{\circ} \mathrm{C}, 1 \mathrm{~min}$ at $60^{\circ} \mathrm{C}$ ) in a volume of $25 \mu$ l with $1 \times$ TaqMan Universal Master Mix (Applied Biosystems). For relative expression among individual donors, mRNA for MICA and MICB was quantified by extrapolating from standard curves and normalized to endogenous control. Standard curves were generated by making serial 10 -fold dilutions using cDNA from cell types found to have high expression of the gene in question.

Killing assays. Cytotoxicity was assessed by standard chromium $\left({ }^{51} \mathrm{Cr}\right)$ release assays. Microglia (15,000 cells/well) were plated in 96-well plates and oligodendrocytes were cultured in 16-well chamber slides. Target cells were incubated overnight at $37^{\circ} \mathrm{C}$ with $1-10 \mu \mathrm{Ci} /$ well of ${ }^{51} \mathrm{Cr}(\mathrm{MP}$ Biomedicals, Mississauga, Ontario, Canada). The next day, cells were washed three times with fresh medium and effector cells were added at varying ratios. Effector cells were isolated or expanded as described above. NKG2D blockade on effector cells was performed by adding $\alpha$ NKG2D-M585 (kindly provided by Amgen) or its isotype at $50 \mu \mathrm{g} / \mathrm{ml}$ for $1 \mathrm{~h}$ at $37^{\circ} \mathrm{C}$ before the killing assay. Anti-MHC class I (W6/32 from eBiosciences, San Diego, CA) or its isotype was also added for $1 \mathrm{~h}$ at $37^{\circ} \mathrm{C}$ before the killing assay in presence of the effector cells. Target cells and effector cells were incubated for $4-5 \mathrm{~h}$ at $37^{\circ} \mathrm{C}$ and then the lysis of target cells was assessed by radioactivity measurement in a gamma counter (Matrix 9600; Canaberra Packard, Mississauga, Ontario, Canada). Effector (E) to target (T) ratios (E:T) used were 3:1 for NK cells and 10:1 for $\gamma \delta$ $\mathrm{T}$ and $\mathrm{CD} 8{ }^{+} \mathrm{T}$ cells. Samples were set up in triplicate and spontaneous release was $<20 \%$ of maximum release. Percent specific lysis was calculated from ${ }^{51} \mathrm{Cr}$ release as follows: (treatment - spontaneous release)/ (maximum release - spontaneous release) $\times 100$. The results are $\mathrm{ex}-$ pressed as the percentage of specific killing.

Immunohistochemistry. Snap-frozen coded sections $\left(\sim 1 \mathrm{~cm}^{2}\right.$ and 10 $\mu \mathrm{m}$ thick) cut from four blocks of brain tissue containing MS lesions from two cases of MS (both patients had MS for at least 20 years and died of bronchopneumonia, one 65 years old male and one 47 years old female) and two blocks of brain white matter from two normal control donors (one 34 years old male who died of myocardial infarction and one 73 years old female who died of aortic aneurysm) were received from the NeuroResource tissue bank, University College London, Institute of Neurology, London, UK. Sections cut before, in the middle of, and immediately after the ones used for the immunofluorescence studies were stained with oil red $\mathrm{O}$ and hematoxylin, and scored as described previously (Li et al., 1996). Serial sections from these six blocks were air-dried and fixed in cold acetone for $10 \mathrm{~min}$. Sections were blocked for nonspecific binding for $1 \mathrm{~h}$ in HHGB [HBSS containing 10\% goat serum, 2\% horse serum, 2\% fetal bovine serum, $1 \mathrm{~mm}$ HEPES buffer and $0.1 \%$ sodium azide] and then blocked for endogenous biotin or biotin-binding proteins using the Blocking Kit from Vector Laboratories (Burlingame, CA) following the manufacturer's instructions. All antibodies were diluted in HHGB and washes were in PBS. Primary, secondary, and tertiary antibodies are listed in Table 1 with their commercial source, isotype, and concentration used.

Costaining for MICA/B and APC, a marker for oligodendrocyte cell body detected with $\mathrm{CC} 1 \mathrm{Ab}$, or GFAP, a marker for astrocytes, was performed by incubating the sections overnight at $4^{\circ} \mathrm{C}$ with anti-MICA/B antibody. Sections were then washed and incubated for $2 \mathrm{~h}$ in biotinylated polyclonal goat-anti-mouse, using a greater concentration (1:100) than recommended and known to saturate all sites on the first primary mouse antibodies and not allowing an FITC-conjugated polyclonal goatanti mouse to bind to the mouse immunoglobulin. Sections were washed and incubated for $1.5 \mathrm{~h}$ with $\mathrm{Cy} 3$-conjugated streptavidin and then double-stained using anti-APC (clone CC1) or Alexa Fluor 488 conjugated anti-GFAP for $2 \mathrm{~h}$ at room temperature, then secondary antibodies (for CC1, FITC-conjugated polyclonal goat anti-mouse) were incubated for $1.5 \mathrm{~h}$ at room temperature.

Staining for myelin-associated glycoprotein (MAG) and GFAP was performed similarly on adjacent sections: MAG antibody was first added, then biotinylated polyclonal goat-anti-mouse, and then Cy3-conjugated streptavidin in the presence of Alexa-488-conjugated GFAP.

Stainings for MICA/B and CD8 were performed similarly on adjacent sections: MICA/B staining was performed first as described above and then CD8 staining was done using anti-CD8 conjugated to allophycocyanin as a primary antibody, followed by rabbit anti-allophycocyanin serum, and finally a donkey anti-rabbit serum conjugated to FITC.

After the last $\mathrm{Ab}$ incubation, all sections were washed and incubated for 10 min with Hoechst 33258 nuclear stain (Invitrogen). To quench tissue autofluorescence, sections were treated with $1 \%(\mathrm{w} / \mathrm{v})$ Sudan black (Sigma) in $70 \%$ ethanol for 3 min after all antibody incubations, and washed thoroughly. Control stainings were performed using appropriate primary isotype controls at the same concentrations and performed on adjacent sections concurrently for MICA/B [IgG2a (Sigma)], CC1 [IgG2b (Sigma)], and GFAP [Alexa Fluor 488-conjugated IgG1 (Caltag)]. Slides were observed using a Leica (Nussloch, Germany) fluorescent microscope or a Leica confocal microscope SP5.

\section{Results}

\section{Differential expression of NKG2D ligands by human} neural cells

We performed flow cytometric analyses to determine whether primary cultures of human CNS cells express NKG2D ligands. CNS cells were obtained from either adult (oligodendrocytes, astrocytes) or fetal material (astrocytes, neurons, microglia) us- 


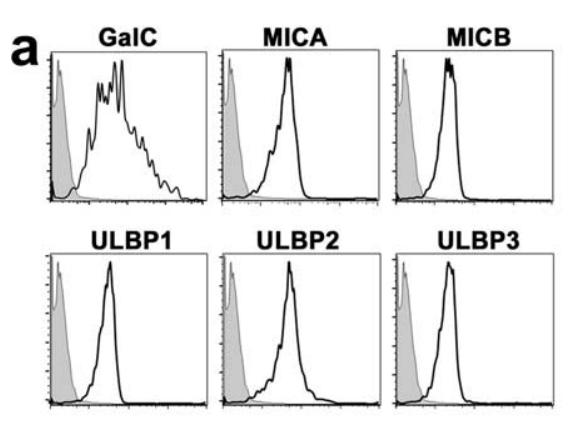

C
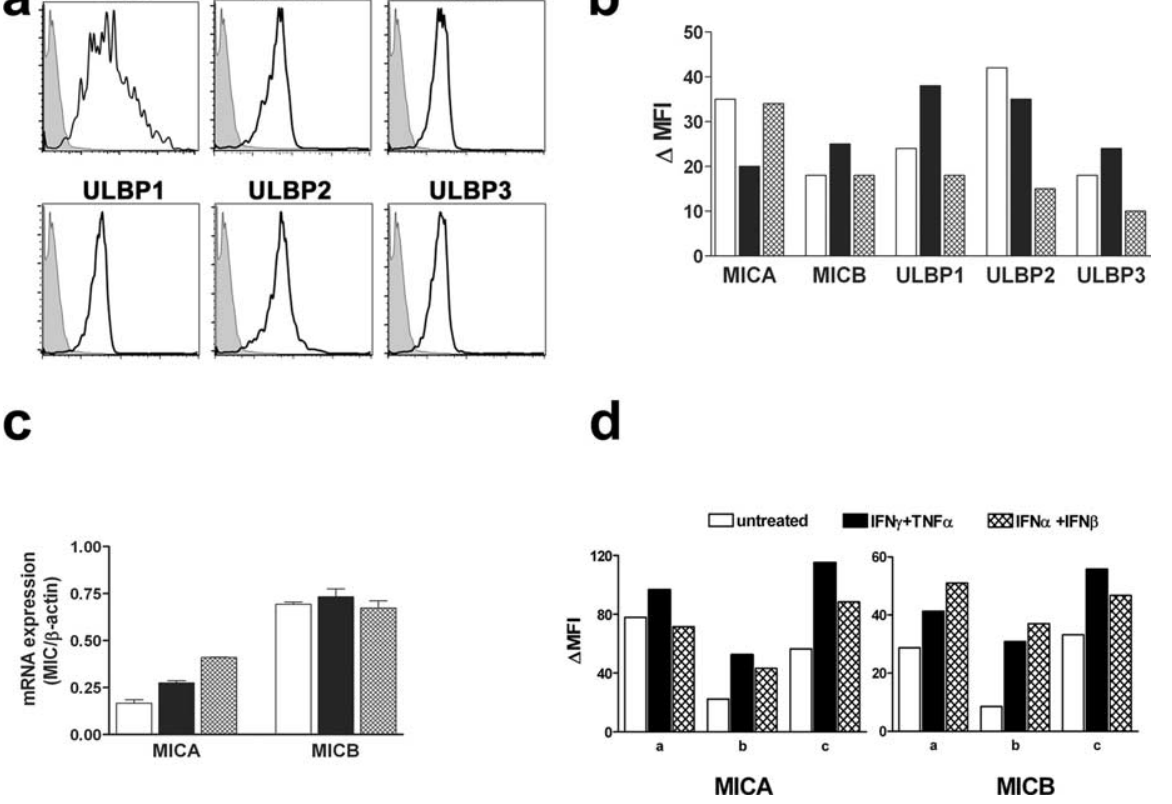

Figure 1. Human adult oligodendrocytes express NKG2D ligands at the protein and mRNA levels. $\boldsymbol{a}$, GalC-positive human oligodendrocytes were analyzed by flow cytometry for MICA, MICB, ULBP1, ULBP2, and ULBP3. Results obtained from one CNS sample are illustrated. Shaded histograms show the corresponding isotype control whereas the back line depicts specific antibody staining. $\boldsymbol{b}$, The MFI of the isotype was subtracted from the mean fluorescence of the staining ( $\Delta \mathrm{MFI})$ for three independent human oligodendrocyte samples tested for MICA, MICB, ULBP1, ULBP2, and ULBP3. Each oligodendrocyte sample is illustrated by a different color: white, gray, and black on histograms. c, mRNA from three distinct oligodendrocyte samples were tested by $q-P C R$ for MICA and MICB. Relative mRNA expression using standard curves for $q P C R m R N A$ quantification and normalizing to $\beta$-actin is illustrated. $\boldsymbol{b}, \boldsymbol{c}$, Each oligodendrocyte sample is illustrated by a different color: white, gray, and black on histograms. $\boldsymbol{d}, 0$ ligodendrocytes were treated with either IFN- $\gamma$ plus TNF- $\alpha$ or IFN- $\alpha$ plus IFN- $\beta$ for $2 \mathrm{~d}$ and then MICA and MICB surface expression was assessed by flow cytometry. $\Delta$ MFI for three independent human oligodendrocyte samples are illustrated. Error bars indicate $S E M$.

ing a mechanical and enzymatic digestion (trypsin) and cultured to enrich for the different cell populations. NKG2D ligand detection was trypsin-sensitive (data not shown on immortalized cell lines); thus, freshly isolated cells could not be used for flow cytometry assessment. Adult human cells (oligodendrocytes and astrocytes) were used 1 week after cell isolation when they have reacquired their physiological characteristics with their cell processes regrown and expression of myelin proteins [i.e., MAG and myelin basic protein as published previously (Ruffini et al., 2004) for oligodendrocytes]. Human CNS cells used in our study were highly enriched (>90\%) as described previously (D'Souza et al., 1995; Jurewicz et al., 1998), and all analyses were performed on cells gated for the typical cell marker. Fetal cells were used either 1 week after cell isolation (microglia) or 2 weeks (neurons, after three treatments of Dfu) or $\sim 1$ month after (astrocytes, time to decrease the proportion of neurons).

Human oligodendrocytes identified by the expression of the specific marker GalC (Fig. 1a) expressed detectable levels of all NKG2D ligands (Fig. 1a, MICA, MICB, ULBP1, ULBP2, ULBP3). NKG2D ligand expression was quantified by calculating the mean fluorescent intensity of the staining minus the mean fluorescent intensity of the background isotype control ( $\Delta \mathrm{MFI})$ for oligodendrocytes obtained from three donors. Although the expression varied between different donors, we detected the five ligands on all oligodendrocyte samples (Fig. $1 b$ ) with a $\Delta$ MFI of at least 10. Using q-PCR, we also detected MICA and MICB transcripts in three different oligodendrocyte samples tested (Fig. 1c), further corroborating that human oligodendrocytes expressed NKG2D ligands. Because of limitations in the amount of available surgically resected tissue, results obtained for protein and
mRNA expression were performed on different oligodendrocyte samples.

To evaluate whether the expression of NKG2D ligands is a common feature of human CNS cells, we tested other cell types. Human fetal and adult astrocytes, expressing the specific marker GFAP, were also analyzed for NKG2D ligand expression. Fetal astrocytes obtained from three donors were shown to express at least one ligand of both groups MICs and ULBPs, albeit at different levels (data not shown). However, adult astrocytes did not express detectable levels of NKG2D ligands when tested with the same antibodies by flow cytometry. Fetal neurons obtained from three donors were tested for the expression of these ligands. We readily detected the expression of Tubulin-III, a neuronal marker, by flow cytometry but we did not observe NKG2D ligands on any of the tested samples (data not shown). Treating neurons for $3 \mathrm{~d}$ with either IL- $1 \beta$ or the combination of IFN- $\gamma$ and TNF- $\alpha$ also did not induce a detectable expression level of NKG2D ligands. We also examined human fetal microglia, which are the resident macrophages of the CNS and could be identified by the expression of CD68. Microglia from two donors did not express detectable levels of NKG2D ligands on their surface (data not shown), although they expressed considerable levels of MHC class I molecules.

Because sustained inflammation has been shown to induce aberrant or higher levels of NKG2D ligands in human inflammatory diseases such as celiac disease and rheumatoid arthritis (Groh et al., 2003; Hue et al., 2004), we tested whether proinflammatory mediators could modulate the expression of NKG2D ligands on oligodendrocytes. Oligodendrocytes obtained from three donors were treated for $2 \mathrm{~d}$ with IFN- $\alpha$ plus IFN- $\beta$ or the combination IFN- $\gamma$ plus TNF- $\alpha$ and then evaluated for their MIC expression by flow cytometry; $\Delta$ MFI for MICA and MICB are illustrated in Figure $1 d$. Oligodendrocytes expressed detectable levels of MICs (Fig. 1d) and MHC class I molecules (data not shown) without any treatment, but increased the expression of these molecules (Fig. 1d, MICA, MICB) after the $2 \mathrm{~d}$ treatment. The upregulated MICA expression induced by either treatment was not statistically significant (untreated vs TNF- $\alpha$ plus IFN- $\gamma$, $p=0.095$; untreated vs IFN- $\alpha$ plus IFN- $\beta, p=0.30$ ) compared with control. However, the upregulation of MICB expression was significant compared with untreated cells for both treatments $(p<0.04)$.

NKG2D ligands were expressed at lower levels by adult human oligodendrocytes $(\Delta \mathrm{MFI}<50)$ and fetal astrocytes $(\Delta \mathrm{MFI}<75)$ compared with a human glioma cell line U251 ( $\Delta$ MFI: MICA, 635; ULBP2, 161; ULBP3, 442).

We were not able to detect MICA/B on oligodendrocytes in vitro by immunocytochemistry, although we could detect such ligands on HeLa cells (data not shown). These results are not surprising because flow cytometry is known to have a greater sensitivity over immunohisto/cytochemistry and HeLa cells ex- 
a
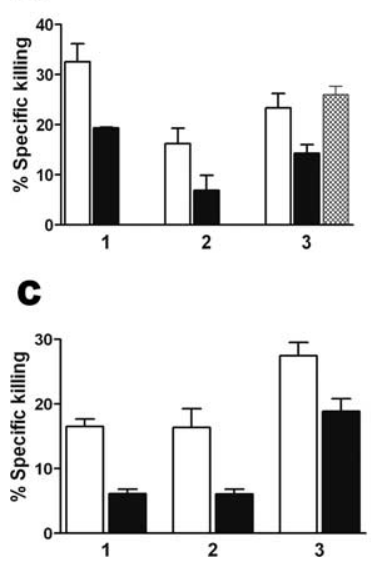

b

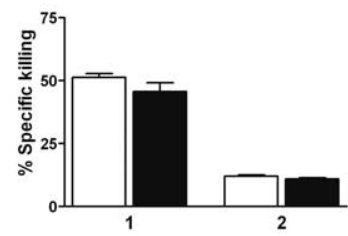

d

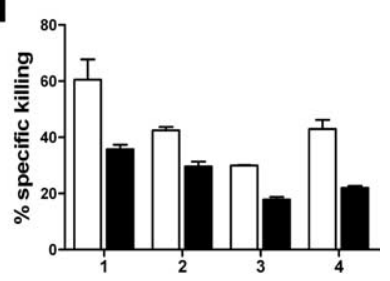

Figure 2. Contribution of the NKG2D-NKG2D ligand interaction to NK cells, $\gamma \delta$ T cells, and $\mathrm{CD}^{+} \mathrm{T}$ cells mediated killing of human oligodendrocytes. $\boldsymbol{a}, \boldsymbol{b}$, IL-2 activated NK cells (effector) were preincubated for $1 \mathrm{~h}$ with either an isotype control (white bars), $\alpha$-NKG2D antibody (black bars), or $\alpha$-MHC class I (gray bars) before being added to ${ }^{51} \mathrm{Cr}$-labeled targets: human adult oligodendrocytes $(\boldsymbol{a})$ or fetal microglia $(\boldsymbol{b})$ at a 3:1 (E:T) ratio. Results obtained from different donors of NK cells on different CNS cell samples $(1,2,3)$ are illustrated. c, Expanded human $\gamma \delta$ $\mathrm{T}$ cells (effector) were preincubated for $1 \mathrm{~h}$ with either an isotype control (white bars) or $\alpha$-NKG2D antibody (black bars) before being added to ${ }^{51} \mathrm{Cr}$-labeled targets: oligodendrocytes at a 10:1 (E:T) ratio. Results obtained from three different donors $(1,2,3)$ of $\gamma \delta$ T cells on different CNS cell samples are illustrated. $\boldsymbol{d}$, Allo-reactive human CD8 ${ }^{+} \mathrm{T}$ cells (effector) were preincubated for $1 \mathrm{~h}$ with either an isotype control (white bars) or $\alpha$-NKG2D antibody (black bars) before being added to ${ }^{51} \mathrm{Cr}$-labeled targets: oligodendrocytes at a 10:1 (E:T) ratio. Results obtained from three different donors ( 3 and 4 are the same CD8 ${ }^{+}$T cell donor) on different oligodendrocyte samples ( 2 and 3 are performed using two CD8 ${ }^{+} \mathrm{T}$ cell donors on the same oligodendrocyte sample) are shown. Paired $t$ tested comparing isotype versus $\alpha$-NKG2D showed a statistical difference between groups for $\boldsymbol{a}(p=0.02)$, c ( $p=$ $0.003)$, and $\boldsymbol{d}$ ( $p=0.018$ ), but not for $\boldsymbol{b}$. Data are presented as percentage of specific killing. Error bars indicate SEM.

press much higher levels of MICs $(\Delta \mathrm{MFI}>160)$ compared with human oligodendrocytes $(\Delta \mathrm{MFI}<50)$.

\section{NKG2D-mediated cytotoxicity of NKG2D ligand-expressing human glial cells}

Our group has shown previously that primary cultures of human oligodendrocytes, astrocytes and microglia can be killed in vitro by activated autologous or heterologous NK cells (Morse et al., 2001). We assessed whether an NKG2D-dependent mechanism was involved in the activated NK cell-mediated cytotoxicity of these cells, which, as indicated above, differ in their expression of NKG2D ligands. IL-2-activated NK cells purified from human PBMCs were used as effector cells in killing assays. NK cells were preincubated with an isotype control (Fig. 2, white bar) or antiNKG2D antibody (Fig. 2, black bar) for $1 \mathrm{~h}$ before being added to ${ }^{51} \mathrm{Cr}$-labeled target cells. Activated NK cells obtained from different donors were able to kill adult oligodendrocytes, or fetal microglia in a $4-5 \mathrm{~h}{ }^{51} \mathrm{Cr}$ release assay at the E:T ratio of $3: 1$, although the extent of killing varied between donors (Fig. $2 a, b$ ). The specific killing mediated by NK cells on adult oligodendrocytes (Fig. 2a, 1 and 2 represent two NK donors on the same oligodendrocyte sample and 3 represents a third NK donor on a second oligodendrocyte sample) was significantly inhibited (34$57 \%$ compared with the isotype control; $p=0.016)$ when NK cells were preincubated with anti-NKG2D, demonstrating the importance of this receptor in cytotoxicity. The NKG2D blockade was specific and not caused by steric hindrance, because an MHC class I antibody, used at the same concentration as the
anti-NKG2D antibody, added to the NK cells and binding to NK cells did not inhibit killing of oligodendrocytes (Fig. 2a, gray histogram). Activated NK cells killed fetal microglia to the same extent whether or not NKG2D was blocked (Fig. 2b, two different NK donors on two different microglia samples are illustrated). Our observations demonstrate that the NKG2D blocking did not nonspecifically inhibit NK-mediated killing and that, although human microglia are susceptible to NK-mediated cytotoxicity, it does not primarily involve NKG2D-NKG2D ligand interactions. Fetal astrocytes were also susceptible to NKG2D-mediated NK cell cytotoxicity as the anti-NKG2D antibody significantly blocked such killing (data not shown) (over 35\% inhibition; $p=$ 0.003 ). These data support the specificity of these blocking experiments.

To demonstrate the broad recognition of NKG2D ligands on human CNS cells by different immune effectors, we used human $\gamma \delta \mathrm{T}$ cells as effector cells. $\gamma \delta \mathrm{T}$ cells have been detected in MS lesions (Wucherpfennig et al., 1992) and shown to kill human oligodendrocytes in vitro (Freedman et al., 1991). In vitro expanded human peripheral $\gamma \delta$ T cells were preincubated with an isotype control (Fig. 2c, white bar) or anti-NKG2D antibody (Fig. $2 c$, black bar) for $1 \mathrm{~h}$ before being added to ${ }^{51} \mathrm{Cr}$-labeled oligodendrocytes. The specific $\gamma \delta$ T cell-mediated killing of oligodendrocytes (Fig. $2 c, 2$ and 3 represent two different $\gamma \delta$ T cell donors on the same oligodendrocyte sample and 1 represents a third $\gamma \delta \mathrm{T}$ cell donor on a different oligodendrocyte sample) was significantly inhibited (31-63\% compared with the isotype control) by preincubation with anti-NKG2D antibody (isotype vs antiNKG2D; $p=0.0037$ ).

We also tested whether NKG2D ligands on human adult oligodendrocytes could be recognized by activated human $\mathrm{CD} 8{ }^{+} \mathrm{T}$ cells because these immune cells have been detected in MS lesions and can partake in the tissue destruction (Friese and Fugger, 2005). Because the percentage of killing obtained using HLA-A2 (human leukocyte antigen A2)-restricted myelin-specific CD8 ${ }^{+}$ $\mathrm{T}$ cells has been shown to be very low ( $<15 \%$ specific killing) (Jurewicz et al., 1998), we have elected to use human allo-reactive $\mathrm{CD}^{+} \mathrm{T}$ cells as effector cells and could detect $30-60 \%$ specific killing on human adult oligodendrocytes (Fig. $2 d$ ). The specific $\mathrm{CD}^{+}{ }^{+} \mathrm{T}$ cell-mediated killing of oligodendrocytes (Fig. $2 d$ ) was significantly inhibited (30-49\% compared with the isotype control) by preincubation with anti-NKG2D antibody (isotype vs anti-NKG2D; $p=0.018)$. These experiments were performed on two different oligodendrocyte samples ( 2 and 3 are the same oligodendrocyte sample) with three different CD8 T cell donors.

These results indicate that human oligodendrocytes express functionally significant amounts of NKG2D ligands that can contribute to their susceptibility to NKG2D-mediated killing by both NK cells and $\gamma \delta \mathrm{T}$ cells, and serve as costimulatory molecules involved in $\mathrm{CD}^{+}{ }^{+} \mathrm{T}$ cell mediated cytotoxicity.

\section{NKG2D ligands are expressed in MS lesions by oligodendrocytes}

To assess whether NKG2D ligands could also be expressed in vivo by human CNS cells, we performed immunohistochemistry on MS lesions in four tissue blocks and normal control white matter from two normal control cases. Active MS lesions were characterized by the presence of many large oil red O-positive macrophages, indicating ongoing or recent demyelination and immune cell perivenular cuffing. The MS sections were complex because they contained large active and subacute plaques, and also some chronic plaques and small areas of normal-appearing white and gray matter. T cell infiltrates were identified with immunohisto- 

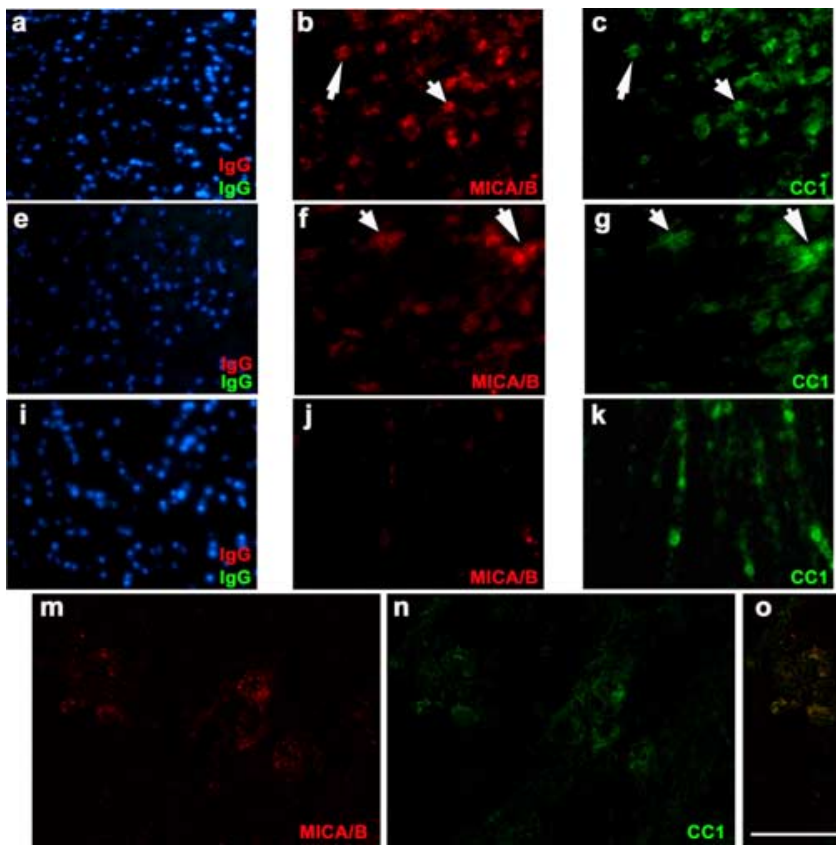

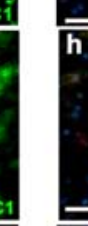
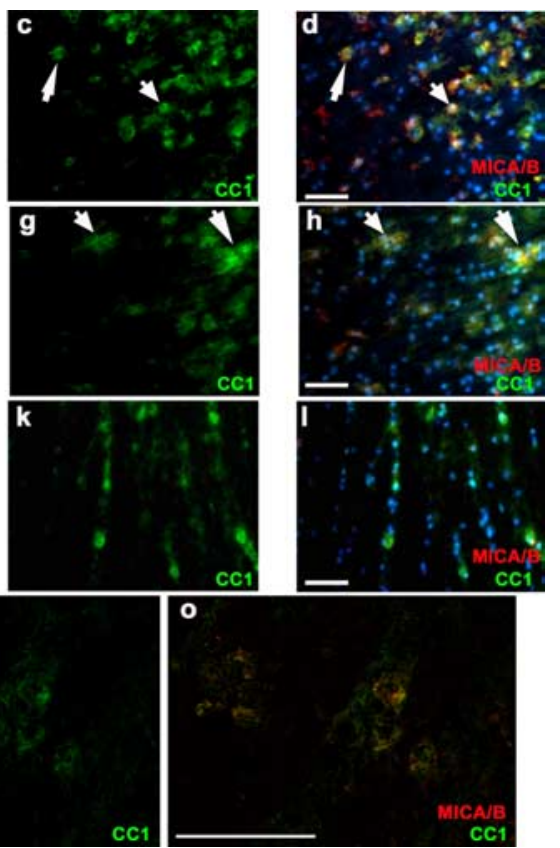

Figure 3. Oligodendrocytes in active MS lesions express NKG2D ligands. $\boldsymbol{a}-\mathbf{0}$, Multiple sections of two active MS lesions (lesion 1: $\boldsymbol{a}-\boldsymbol{d}, \boldsymbol{m}-\boldsymbol{o}$; lesion 2: $\boldsymbol{e}-\boldsymbol{h}$ ) and one control (i-I) were immunostained for MICA/B (red), followed by CC1 staining for oligodendrocytes (green). $\boldsymbol{a}, \boldsymbol{e}$, and $\boldsymbol{i}$ show corresponding isotype controls performed simultaneously on adjacent sections. $\boldsymbol{b}, \boldsymbol{f}$, and $\boldsymbol{j}$ show MICA/B staining of sections (red); $\boldsymbol{c}, \boldsymbol{g}$, and $\boldsymbol{I}$ display immunolabeling with CC1 (green), and $\boldsymbol{d}$ and $\boldsymbol{h}$ show an overlay of MICA/B and $\mathrm{CC}$, along with Hoechst nuclear stain. There is overlay of MICA/B and CC1 stains as seen by the orange-yellowish color on multiple cells ( $\boldsymbol{d}$, $\boldsymbol{h}$ ); white arrows are examples of double-labeled cells in MS lesions. Original magnification of pictures was $40 \times$. Scale bar, $50 \mu \mathrm{m}$. Confocal images are illustrated in the bottom row $(\boldsymbol{m}-\mathbf{0})$; similar images could be seen throughout the $8 \mu \mathrm{m} z$-stack every $0.2 \mu \mathrm{m}$.
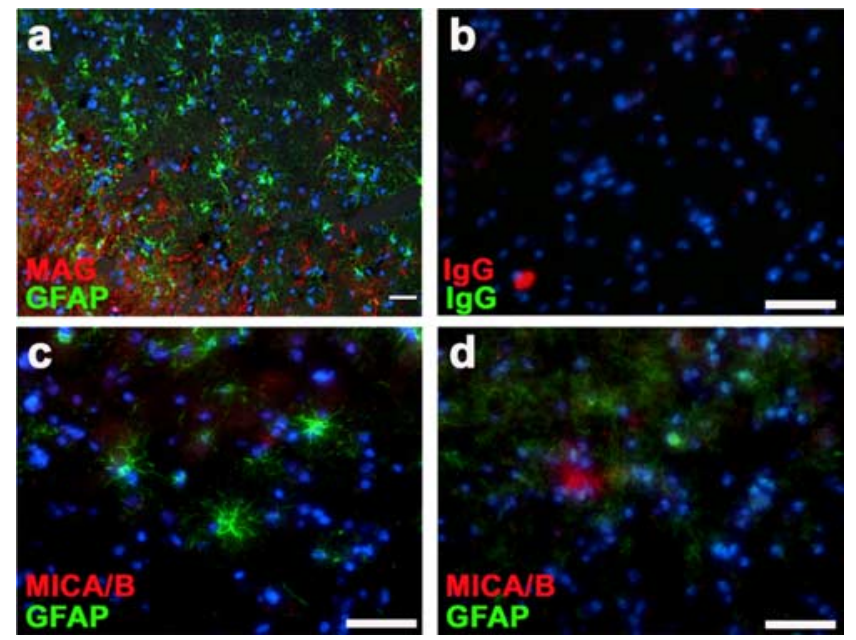

Figure 4. Absence of NKG2D ligands on astrocytes in active MS lesions. One representative active MS lesion is illustrated; the staining for MAG (a) (red), a specific marker of myelin and oligodendrocytes, is shown, and followed by GFAP (green) staining for astrocytes to illustrate the morphology of cell types found in these tissues. The active lesion analysis was performed at the intersection of activated star-shape astrocytes and loss of myelin staining. Sections from normal control white matter demonstrated homogenous staining for MAG (data not shown). $c$, $\boldsymbol{d}$, Sections were stained for MICA/B (red), followed by GFAP (green) staining for astrocytes. MICA/B + cells did not colocalize with GFAP staining. Different areas of the same sections are shown to illustrate the distinct GFAP staining observed. $\boldsymbol{b}$, Isotype controls performed simultaneously on adjacent sections of the active MS lesions are illustrated. Scale bar $50 \mu \mathrm{m}$.

chemistry in the parenchyma of the active lesions, as well as in perivenular cuffs. We restricted our analysis to the active lesions because chronic lesions had higher background and tissue disorganization.

Normal control and MS sections were stained with Abs immunohistochemistry in CNS tissue sections and by flow cytometry, but not immunocytochemistry in vitro, suggests a greater expression of MICA/B than what we observed on the primary cultures of CNS cells in vitro.

As mentioned above, we focused our analysis on active lesions as illustrated in Figure $4 a$ (MAG and GFAP staining) where the GFAP + cells had the typical star shape of activated astrocytes. $\mathrm{MICA} / \mathrm{B}+$ cells did not colocalize with GFAP + cells in MS lesions (Fig. 4) in the active part of the lesions. We also observed some MICA/B + cells, mainly around blood vessels that were not identified by GFAP or CC1 labeling, suggesting that other cell types may bear detectable levels of NKG2D ligands in the inflamed CNS. Only very rare isolated $\mathrm{MICA} / \mathrm{B}^{+}$cells were seen in normal control white matter and none of these rare cells costained with either CC1 (Fig. 3) or GFAP (data not shown).

Because $\mathrm{CD}^{+}{ }^{+} \mathrm{T}$ cells have been detected by many groups in MS lesions (for review, see Friese and Fugger, 2005), we tested whether such immune effector cells could be in close proximity to the MICA/B expressing cells (mainly oligodendrocytes in the active MS lesions we tested). As illustrated in Figure 5, CD8 ${ }^{+}$T cells were easily detected in the parenchyma of MS lesions (Fig. 5b), but were mainly seen only in the blood vessels of the nonneurological disease control (Fig. $5 f$ ). We could observe CD ${ }^{+} \mathrm{T}$ cells in close proximity to MICA/B ${ }^{+}$cells in active MS lesions, supporting the recognition of NKG2D ligands by $\mathrm{CD} 8{ }^{+} \mathrm{T}$ cells during MS pathogenesis. These observations were confirmed using a high magnification by confocal microscopy where two different $z$-stack layers from the same field are illustrated (Fig. 5i,j).

\section{Discussion}

Our results show that NKG2D ligands were selectively expressed by human primary oligodendrocytes in the CNS. Such expression 
provides a contributing mechanism to the previously observed MHC restricted and nonrestricted immune-mediated cytotoxicity directed at these cells. Adult oligodendrocytes (and only fetal astrocytes) expressed NKG2D ligands of both groups: MICs and ULBPs. The flow cytometry profiles suggest that all oligodendrocytes and not subsets of these cells expressed the ligands. We observed lower amounts of NKG2D ligands as compared with those on a human glioma cell line U251 tested under the same conditions, consistent with previous reports of high MIC and ULBP levels on various human tumors, including brain tumors (Groh et al., 1999; Pende et al., 2002; Jinushi et al., 2003). We used oligodendrocytes derived from nontumoral surgical adult brain tissues and maintained under basal culture conditions for 1 week; thus, cells had the time to recover from any stress induced by the isolation and displayed characteristic cell processes. Expression of MICs was upregulated on oligodendrocytes (Fig. 1) by cytokines (IFN- $\alpha$ plus IFN- $\beta$ and TNF- $\alpha$ plus IFN- $\gamma$ ), suggesting that immune mediators can enhance such expression.

TNF- $\alpha$ and IFN- $\gamma$ are relevant in the context of human diseases because they have been detected in elevated amounts in multiple CNS inflammatory pathologies including MS (Probert and Selmaj, 1997; Benveniste, 1998; Owens, 2002; Basu et al., 2004; Magnano et al., 2004). We have shown previously that toll-like receptor ligation on human adult microglia led to IFN- $\beta$ expression (Jack et al., 2005), suggesting a potential in situ source of this cytokine. The same cytokine combinations (IFN- $\alpha$ plus IFN- $\beta$ and TNF- $\alpha$ plus IFN- $\gamma$ ) also increased the expression of MHC class I on human oligodendrocytes (data not shown). Therefore, these cells could become more susceptible to MHC-class I restricted $\mathrm{CD}^{+}{ }^{+} \mathrm{T}$ cell-mediated killing. Our data indicate that CNS glial cells, such as oligodendrocytes, are not passive cells during MS pathogenesis. Oligodendrocytes can contribute to the dialogue between the immune system and the CNS by providing ligands (NKG2D ligands and MHC class I) in greater amounts in response to environmental signals, and therefore enhance the interaction with immune effectors.

Neurons derived from human fetal cerebral tissue did not express detectable levels of NKG2D ligands. We postulate that the absence of NKG2D ligands on neurons may, similarly to the low or undetectable MHC class I molecule expression, serve as a protective mechanism from immune-mediated injury (Neumann et al., 1995; Redwine et al., 2001). Our results parallel what has been described for mouse CNS-derived neurons (Backstrom et al., 2003). Although peripheral nerve neurons (i.e., dorsal root ganglia neurons) expressed high levels of the mouse NKG2D ligand [RAE-1 (retinoic acid early inducible gene-1)] and were killed by NK cells via NKG2D, CNS-derived neurons expressed only very low levels and were resistant to NK-mediated killing (Backstrom et al., 2003). Human microglia also did not express detectable levels of NKG2D ligands. ULBP proteins have been detected during granular/monocyte differentiation of $\mathrm{CD} 34^{+}$hematopoietic progenitors (Guilloton et al., 2005; Nowbakht et al., 2005) and subsets of human macrophages have been shown to express
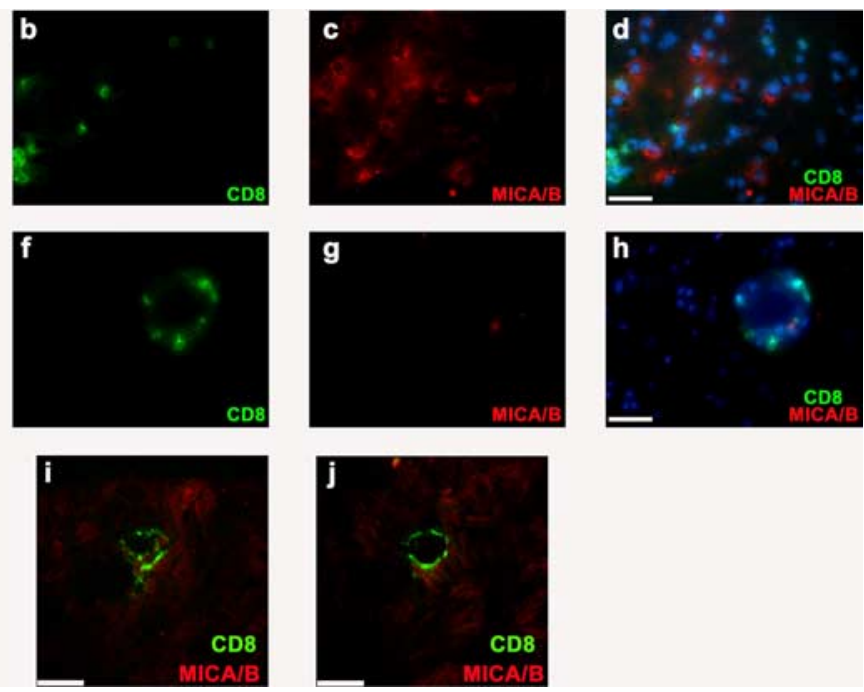

CD8

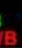

Figure 5. $C D 8{ }^{+} \mathrm{T}$ cells in close proximity to MICA/B + cells in active MS lesions. MS lesions and controls were stained for CD8 (green) and MICA/B (red). $\boldsymbol{a}-\boldsymbol{j}$, One representative active MS lesion $(\boldsymbol{a}-\boldsymbol{d}, \boldsymbol{i}, \boldsymbol{j})$ and one representative control $(\boldsymbol{e}-\boldsymbol{h})$ are illustrated. contact with MICA/B + cells are presented from the same field at two distinct $z$-stack positions to illustrate the close contact : (in $\boldsymbol{d}, \boldsymbol{h}) \boldsymbol{a}-\boldsymbol{h}, 50 \mu \mathrm{m} ; \boldsymbol{i}, \boldsymbol{j}, 7.5 \mu \mathrm{m}$.

NKG2DL especially after a bacterial infection (Vankayalapati et al., 2005). NKG2D ligands are generally expressed early in embryonic life before NK cell generation (Cerwenka and Lanier, 2001), but disappear when NK cells are produced early in life (Raulet et al., 2001).

The distinct expression of NKG2D ligands on adult oligodendrocytes even at relatively low levels compared with tumor cells, as previously mentioned, was sufficient to allow cytotoxic interactions with immune effector cells. Oligodendrocytes were killed in a $4-5 \mathrm{~h}{ }^{51} \mathrm{Cr}$ release assay by activated NK cells as expected (Morse et al., 2001). Moreover, we demonstrated that blocking NKG2D interaction with its ligands inhibited NK-mediated killing of human oligodendrocytes. $\gamma / \delta$ T cell-mediated and CD ${ }^{+} \mathrm{T}$ cell-mediated killings of human oligodendrocytes were also partially inhibited by blocking NKG2D. Because we were not able to completely abrogate $\mathrm{NK}, \gamma / \delta \mathrm{T}$, or $\mathrm{CD} 8{ }^{+} \mathrm{T}$ cell-mediated killing of human oligodendrocytes, it is possible that additional activating receptors could play a role in the observed cytotoxicity. Blocking MHC class I molecules did not affect the NK-mediated killing (Fig. 2), confirming that the NKG2D blocking was not caused by steric hindrance. We also performed a flow cytometrybased experiment to show that NK cells incubated with antiNKG2D Ab maintained their content of granzymes and perforin, which are essential lytic enzymes for cytotoxicity (data not shown). Microglia did not express NKG2D ligands and their susceptibility to NK-mediated killing could not be blocked with anti-NKG2D antibody (Fig. $2 b$ ) suggesting that such cytotoxicity was mediated via other activating receptors such as the natural cytotoxicity receptors: NKp46, NKp30, and NKp44 (Raulet, 2003; Lanier, 2005). Our results indicate that human oligodendrocytes are susceptible to $\mathrm{NK}, \gamma / \delta \mathrm{T}$, and $\mathrm{CD} 8^{+} \mathrm{T}$ cell-mediated killing via the engagement of NKG2D by NKG2D ligands on their surface. These three activated cell types have been shown previously to kill oligodendrocytes in vitro, but no common mechanism(s) used by these effector cells has been reported before. 
Engagement of NKG2D on NK cells and $\gamma / \delta$ T cells leads to the killing of NKG2D ligand-bearing cells and secretion of proinflammatory cytokines (Raulet, 2003; Andre et al., 2004; RinconOrozco et al., 2005). However, NKG2D on human CD8 ${ }^{+}$T cells has been shown to be a coactivator molecule that can replace the CD28-coactivation provided by B7 molecules (Raulet, 2003; Andre et al., 2004). Moreover, there is an increased frequency of $\mathrm{T}$ cells that are CD28 negative in patients affected with an autoimmune disease including MS (Markovic-Plese et al., 2001; Warrington et al., 2001), suggesting that these T cells could use other coactivating molecules such as NKG2D ligands. Our observations provide a novel distinct ligand-receptor interaction contributing to the potentially detrimental dialogue between oligodendrocytes and immune cells.

The relevance of NKG2D ligand expression in human inflamed CNS to the MS disease process is supported by our preliminary observations that MICA/B was detected by immunohistochemistry in active white matter lesions, especially in tissue at the edges of demyelinating lesions (Figs. 3, 5), but not in normal control white matter (Fig. 3). NKG2D ligands have been reported on human gliomas of grades II, III, and IV but, were undetectable in normal control white matter or very low only on reactive astrocytes, confirming our observations (Eisele et al., 2006). Our (in vitro) data demonstrated that NKG2D ligand expression can be increased by IFN- $\gamma$ plus TNF- $\alpha$ or IFN- $\alpha$ plus IFN- $\beta$ on oligodendrocytes. We observed high NKG2D ligand expression on oligodendrocytes preferentially in MS lesions in the same areas as large oil red O positive macrophages. Consequently, these activated macrophages present in the disease environment could secrete mediators contributing to these augmented NKG2D ligand expression on oligodendrocytes. MICA/ $\mathrm{B}^{+}$cells were detected in groups and many of them costained for APC/CC1, a specific marker for oligodendrocytes (Fig. 3). No colocalization with GFAP was observed (Fig. 4). Cells other than astrocytes and oligodendrocytes were also $\mathrm{MICA} / \mathrm{B}^{+}$suggesting that additional cell types, mainly around blood vessels, could bear detectable levels of NKG2D ligands in the inflamed CNS. Detectable NKG2D ligand expression both in vitro and in vivo by human oligodendrocytes and not by other CNS cell types (neurons, microglia, adult astrocytes) could contribute to the oligodendrocyte/myelin injury that characterizes MS.

The relevance of NKG2D-NKG2D ligand interaction in detrimental autoimmune responses has been demonstrated in animal models; these observations validate the development of putative therapies aimed at blocking such an interaction. In an animal model of diabetes, it has been shown that nondepleting anti-NKG2D antibody treatment during the prediabetic stage of non-obese diabetic mice completely prevented disease by impairing the expansion and function of autoreactive $\mathrm{CD}^{+} \mathrm{T}$ cells (Ogasawara et al., 2004). In a $\gamma \delta$ T cell-induced demyelination mouse model, NKG2D blockade reduced oligodendrocyte death and myelin loss up to $60 \%$ suggesting that oligodendrocytes could be killed via a NKG2D-mediated mechanism by $\gamma \delta \mathrm{T}$ cells (Dandekar et al., 2005) in vivo. Our observations also provide a novel mechanism by which immune effectors can selectively damage human oligodendrocytes during CNS inflammation.

\section{References}

Andre P, Castriconi R, Espeli M, Anfossi N, Juarez T, Hue S, Conway H, Romagne F, Dondero A, Nanni M, Caillat-Zucman S, Raulet DH, Bottino C, Vivier E, Moretta A, Paul P (2004) Comparative analysis of human NK cell activation induced by NKG2D and natural cytotoxicity receptors. Eur J Immunol 34:961-971.

Backstrom E, Chambers BJ, Ho EL, Naidenko OV, Mariotti R, Fremont DH,
Yokoyama WM, Kristensson K, Ljunggren HG (2003) Natural killer cell-mediated lysis of dorsal root ganglia neurons via RAE1/NKG2D interactions. Eur J Immunol 33:92-100.

Bahram S (2000) MIC genes: from genetics to biology. Adv Immunol 76:1-60.

Basu A, Krady JK, Levison SW (2004) Interleukin-1: a master regulator of neuroinflammation. J Neurosci Res 78:151-156.

Benveniste EN (1998) Cytokine actions in the central nervous system. Cytokine Growth Factor Rev 9:259-275.

Bien CG, Bauer J, Deckwerth TL, Wiendl H, Deckert M, Wiestler OD, Schramm J, Elger CE, Lassmann H (2002) Destruction of neurons by cytotoxic T cells: a new pathogenic mechanism in Rasmussen's encephalitis. Ann Neurol 51:311-318.

Carbone E, Neri P, Mesuraca M, Fulciniti MT, Otsuki T, Pende D, Groh V, Spies T, Pollio G, Cosman D, Catalano L, Tassone P, Rotoli B, Venuta S (2005) HLA class I, NKG2D, and natural cytotoxicity receptors regulate multiple myeloma cell recognition by natural killer cells. Blood 105:251-258.

Cerwenka A, Lanier LL (2001) Ligands for natural killer cell receptors: redundancy or specificity. Immunol Rev 181:158-169.

Cosman D, Mullberg J, Sutherland CL, Chin W, Armitage R, Fanslow W, Kubin M, Chalupny NJ (2001) ULBPs, novel MHC class I-related molecules, bind to CMV glycoprotein UL16 and stimulate NK cytotoxicity through the NKG2D receptor. Immunity 14:123-133.

Dandekar AA, O'Malley K, Perlman S (2005) Important roles for gamma interferon and NKG2D in $\gamma \delta$ T-cell-induced demyelination in T-cell receptor beta-deficient mice infected with a coronavirus. J Virol 79:9388-9396.

D’Souza S, Alinauskas K, McCrea E, Goodyer C, Antel JP (1995) Differential susceptibility of human CNS-derived cell populations to TNF-dependent and independent immune-mediated injury. J Neurosci 15:7293-7300.

Eisele G, Wischhusen J, Mittelbronn M, Meyermann R, Waldhauer I, Steinle A, Weller M, Friese MA (2006) TGF-beta and metalloproteinases differentially suppress NKG2D ligand surface expression on malignant glioma cells. Brain 129:2416-2425.

Freedman MS, Ruijs TC, Selin LK, Antel JP (1991) Peripheral blood gamma-delta $\mathrm{T}$ cells lyse fresh human brain-derived oligodendrocytes. Ann Neurol 30:794-800.

Friese MA, Fugger L (2005) Autoreactive CD8 + T cells in multiple sclerosis: a new target for therapy? Brain 128:1747-1763.

Gasser S, Orsulic S, Brown EJ, Raulet DH (2005) The DNA damage pathway regulates innate immune system ligands of the NKG2D receptor. Nature 436:1186-1190.

Groh V, Bahram S, Bauer S, Herman A, Beauchamp M, Spies T (1996) Cell stress-regulated human major histocompatibility complex class I gene expressed in gastrointestinal epithelium. Proc Natl Acad Sci USA 93:12445-12450.

Groh V, Rhinehart R, Secrist H, Bauer S, Grabstein KH, Spies T (1999) Broad tumor-associated expression and recognition by tumor-derived gamma delta T cells of MICA and MICB. Proc Natl Acad Sci USA 96:6879-6884.

Groh V, Rhinehart R, Randolph-Habecker J, Topp MS, Riddell SR, Spies T (2001) Costimulation of CD $8 \alpha \beta$ T cells by NKG2D via engagement by MIC induced on virus-infected cells. Nat Immunol 2:255-260.

Groh V, Bruhl A, El-Gabalawy H, Nelson JL, Spies T (2003) Stimulation of T cell autoreactivity by anomalous expression of NKG2D and its MIC ligands in rheumatoid arthritis. Proc Natl Acad Sci USA 100:9452-9457.

Guilloton F, de Thonel A, Jean C, Demur C, Mansat-De Mas V, Laurent G, Quillet-Mary A (2005) TNF $\alpha$ stimulates NKG2D-mediated lytic activity of acute myeloid leukemic cells. Leukemia 19:2206-2214.

Hue S, Mention JJ, Monteiro RC, Zhang S, Cellier C, Schmitz J, Verkarre V, Fodil N, Bahram S, Cerf-Bensussan N, Caillat-Zucman S (2004) A direct role for NKG2D/MICA interaction in villous atrophy during celiac disease. Immunity 21:367-377.

Ip CW, Kroner A, Bendszus M, Leder C, Kobsar I, Fischer S, Wiendl H, Nave KA, Martini R (2006) Immune cells contribute to myelin degeneration and axonopathic changes in mice overexpressing proteolipid protein in oligodendrocytes. J Neurosci 26:8206-8216.

Jack CS, Arbour N, Manusow J, Montgrain V, Blain M, McCrea E, Shapiro A, Antel JP (2005) TLR signaling tailors innate immune responses in human microglia and astrocytes. J Immunol 175:4320-4330.

Jinushi M, Takehara T, Tatsumi T, Kanto T, Groh V, Spies T, Kimura R, 
Miyagi T, Mochizuki K, Sasaki Y, Hayashi N (2003) Expression and role of MICA and MICB in human hepatocellular carcinomas and their regulation by retinoic acid. Int J Cancer 104:354-361.

Jurewicz A, Biddison WE, Antel JP (1998) MHC class I-restricted lysis of human oligodendrocytes by myelin basic protein peptide-specific CD8 T lymphocytes. J Immunol 160:3056-3059.

Lanier LL (2005) NK cell recognition. Annu Rev Immunol 23:225-274.

Li H, Cuzner ML, Newcombe J (1996) Microglia-derived macrophages in early multiple sclerosis plaques. Neuropathol Appl Neurobiol 22:207-215.

Maasho K, Opoku-Anane J, Marusina AI, Coligan JE, Borrego F (2005) NKG2D is a costimulatory receptor for human naive CD8+ T cells. J Immunol 174:4480-4484.

Magnano MD, Robinson WH, Genovese MC (2004) Demyelination and inhibition of tumor necrosis factor (TNF). Clin Exp Rheumatol 22:S134-140.

Markovic-Plese S, Cortese I, Wandinger KP, McFarland HF, Martin R (2001) CD4(+)CD28(-) costimulation-independent T cells in multiple sclerosis. J Clin Invest 108:1185-1194.

Meresse B, Chen Z, Ciszewski C, Tretiakova M, Bhagat G, Krausz TN, Raulet DH, Lanier LL, Groh V, Spies T, Ebert EC, Green PH, Jabri B (2004) Coordinated induction by IL15 of a TCR-independent NKG2D signaling pathway converts CTL into lymphokine-activated killer cells in celiac disease. Immunity 21:357-366.

Mi S, Miller RH, Lee X, Scott ML, Shulag-Morskaya S, Shao Z, Chang J, Thill G, Levesque M, Zhang M, Hession C, Sah D, Trapp B, He Z, Jung V, McCoy JM, Pepinsky RB (2005) LINGO-1 negatively regulates myelination by oligodendrocytes. Nat Neurosci 8:745-751.

Morse RH, Seguin R, McCrea EL, Antel JP (2001) NK cell-mediated lysis of autologous human oligodendrocytes. J Neuroimmunol 116:107-115.

Neumann H, Cavalie A, Jenne DE, Wekerle H (1995) Induction of MHC class I genes in neurons. Science 269:549-552.

Nowbakht P, Ionescu MC, Rohner A, Kalberer CP, Rossy E, Mori L, Cosman D, De Libero G, Wodnar-Filipowicz A (2005) Ligands for natural killer cell-activating receptors are expressed upon the maturation of normal myelomonocytic cells but at low levels in acute myeloid leukemias. Blood 105:3615-3622.

Ogasawara K, Hamerman JA, Ehrlich LR, Bour-Jordan H, Santamaria P, Bluestone JA, Lanier LL (2004) NKG2D blockade prevents autoimmune diabetes in NOD mice. Immunity 20:757-767.

Owens T (2002) Identification of new therapeutic targets for prevention of CNS inflammation. Expert Opin Ther Targets 6:203-215.

Pende D, Rivera P, Marcenaro S, Chang CC, Biassoni R, Conte R, Kubin M, Cosman D, Ferrone S, Moretta L, Moretta A (2002) Major histocompatibility complex class I-related chain A and UL16-binding protein expres- sion on tumor cell lines of different histotypes: analysis of tumor susceptibility to NKG2D-dependent natural killer cell cytotoxicity. Cancer Res 62:6178-6186.

Probert L, Selmaj K (1997) TNF and related molecules: trends in neuroscience and clinical applications. J Neuroimmunol 72:113-117.

Raulet DH (2003) Roles of the NKG2D immunoreceptor and its ligands. Nat Rev Immunol 3:781-790.

Raulet DH, Vance RE, McMahon CW (2001) Regulation of the natural killer cell receptor repertoire. Annu Rev Immunol 19:291-330.

Redwine JM, Buchmeier MJ, Evans CF (2001) In vivo expression of major histocompatibility complex molecules on oligodendrocytes and neurons during viral infection. Am J Pathol 159:1219-1224

Rincon-Orozco B, Kunzmann V, Wrobel P, Kabelitz D, Steinle A, Herrmann $\mathrm{T}$ (2005) Activation of $\mathrm{V} \gamma 9 \mathrm{~V} \delta 2 \mathrm{~T}$ Cells by NKG2D. J Immunol 175:2144-2151.

Ruffini F, Arbour N, Blain M, Olivier A, Antel JP (2004) Distinctive properties of human adult brain-derived myelin progenitor cells. Am J Pathol 165:2167-2175.

Salih HR, Antropius H, Gieseke F, Lutz SZ, Kanz L, Rammensee HG, Steinle A (2003) Functional expression and release of ligands for the activating immunoreceptor NKG2D in leukemia. Blood 102:1389-1396.

Sospedra M, Martin R (2005) Immunology of multiple sclerosis. Annu Rev Immunol 23:683-747.

Tieng V, Le Bouguenec C, du Merle L, Bertheau P, Desreumaux P, Janin A, Charron D, Toubert A (2002) Binding of Escherichia coli adhesin AfaE to CD55 triggers cell-surface expression of the MHC class I-related molecule MICA. Proc Natl Acad Sci USA 99:2977-2982.

Vankayalapati R, Garg A, Porgador A, Griffith DE, Klucar P, Safi H, Girard WM, Cosman D, Spies T, Barnes PF (2005) Role of NK cell-activating receptors and their ligands in the lysis of mononuclear phagocytes infected with an intracellular bacterium. J Immunol 175:4611-4617.

Warrington KJ, Takemura S, Goronzy JJ, Weyand CM (2001) CD4+, CD28-T cells in rheumatoid arthritis patients combine features of the innate and adaptive immune systems. Arthritis Rheum 44:13-20.

Welte SA, Sinzger C, Lutz SZ, Singh-Jasuja H, Sampaio KL, Eknigk U, Rammensee HG, Steinle A (2003) Selective intracellular retention of virally induced NKG2D ligands by the human cytomegalovirus UL16 glycoprotein. Eur J Immunol 33:194-203.

Wucherpfennig KW, Newcombe J, Li H, Keddy C, Cuzner ML, Hafler DA (1992) Gamma delta T-cell receptor repertoire in acute multiple sclerosis lesions. Proc Natl Acad Sci USA 89:4588-4592.

Zeine R, Pon R, Ladiwala U, Antel JP, Filion LG, Freedman MS (1998) Mechanism of $\gamma \delta \mathrm{T}$ cell-induced human oligodendrocyte cytotoxicity: relevance to multiple sclerosis. J Neuroimmunol 87:49-61. 